\title{
Using Clinical and Multislice Computer Tomographic Features to Assess Temporomandibular Joint Osseous Involvement in Rheumatoid Arthritis: A Preliminary Study
}

\author{
Romatid Artritte Osseöz Temporomandibüler Eklem Tutulumunun Klinik ve \\ Çok Kesitli Bilgisayarlı Tomografi Özellikleri: Ön Çalışma
}

\author{
Tamer GHEITA, ${ }^{1}$ Moushira DAHABA, ${ }^{2}$ Eman AHMED, ${ }^{2}$ Shorouk KHALIFA, ${ }^{2}$ Ayman BASMY ${ }^{3}$ \\ ${ }^{1}$ Department of Rheumatology, Faculty of Medicine, Cairo University, Cairo, Egypt; \\ ${ }^{2}$ Department of Oral Radiology, Faculty of Oral Medicine and dentistry, Cairo, Egypt; \\ ${ }^{3}$ Department of Radiodiagnosis, Faculty of Medicine, Cairo University, Cairo, Egypt
}

\begin{abstract}
Objectives: In this study, we aimed to assess the osseous involvement of temporomandibular joint (TMJ) in rheumatoid arthritis (RA) patients by multislice computed tomography (MSCT) scanning with multiplanar reconstruction (MPR), and to find any relation to the clinical, laboratory and radiological disease parameters.

Patients and methods: Twenty-four female patients (mean age $35.5 \pm 6.6$ years; range 38.3 to 42 years) with definite diagnosis of RA were recruited in the study. Assessment was conducted through medical history, physical examination and clinical investigation. Disease Activity Scores in 28 Joints (DAS28) was calculated and Health Assessment Questionnaire-II (HAQ-II) used. The TMJs were assessed according to the TMJ clinical dysfunction score. Radiological grading of hands and feet was performed according to the modified Larsen score. Findings of the MSCT were assessed using the TMJ CT score.
\end{abstract}

Results: Temporomandibular joint involvement was present in $70.83 \%$ of patients. The most commonly seen clinical TMJ dysfunction manifestations were difficult manipulation and pain, tenderness $(45.83 \%)$ clicking (29.17\%), locking (16.67\%), followed by altered mouth opening (8.33\%). The TMJ osseous involvement became more frequent (83.33\%) after using bilateral MPR scan. The most frequent findings were mandibular condyle erosions, altered condyle position, mandibular subchondral sclerosis, articular eminence flattening, altered condyle shape and articular fossa erosion, osteophytes, articular eminence erosion, followed by mandibular subcondral cysts. The mouth opening was obviously reduced in $41.67 \%$ of patients. The TMJ CT score showed a trend to correlate with DAS28 and modified Larsen score.

Conclusion: The MSCT MPR is a diagnostically reliable modality for the estimation of TMJ involvement in relation to the clinical manifestations and disease activity in RA patients. Early assessment is of utmost importance for the RA patients with symptomatic TMJ.

Key words: Multiplanar reconstruction; multislice computed tomography; rheumatoid arthritis; temporomandibular joint.
Amaç: $\mathrm{Bu}$ çalışmada, romatoid artrit (RA) hastalarında çok kesitli bilgisayarlı tomografi (ÇKBT) taraması ve multiplanar rekonstrüksiyon (MPR) ile temporomandibüler eklemin (TME) osseöz tutulumu değerlendirildi ve klinik, laboratuvar ve radyolojik hastalık parametreleri açısından bir ilişki olup olmadığı araştırıldı.

Hastalar ve yöntemler: Çalışmaya kesin RA tanısı konmuş 24 kadın hasta (ort. yaş $35.5 \pm 6.6$ yıl; dağılım 38.3-42 yıl) dahil edildi. Değerlendirme tıbbi öykü, fizik muayene ve klinik araștırma ile gerçekleştirildi. Yirmi sekiz eklemde Hastalık Aktivite Skoru (DAS28) hesaplandı ve Sağlık Değerlendirme Anketi-II (HAQ-II) yapıldı. Hastaların TME'leri TMJ klinik disfonksiyon skoruna göre değerlendirildi. El ve ayakların radyolojik evrelemesi modifiye Larsen skoru esas alınarak yapıldı. Çok kesitli bilgisayarlı tomografi bulguları, TME BT skoru kullanılarak değerlendirildi.

Bulgular: Hastaların \%70.83'ünde TMJ tutulumu mevcuttu. En sık rastlanan klinik TME disfonksiyon belirtileri zorlu manipülasyon ve ağrı, hassasiyet (\%45.83), tık sesi (\%29.17), kilitlenme (\%16.67) ve takiben ağzın değişen ölçülerde açılması (\%8.33) idi.. İki taraflı MRP taramasından sonra daha fazla sayıda hastada osseöz TME tutulumuna rastlandı (\%83.33). En sık rastlanan bulgular mandibuler kondil erozyonları, değişen kondil pozisyonu, mandibuler subkondral skleroz, artiküler eminens düzleşmesi değişen kondil şekli ve artiküler fossa erozyonu, osteofitler, artiküler eminence erozyonu ve takiben mandibuler subkondral kistlerdi. Hastaların \%41.67'sinde ağız açıklığı görünür şekilde azalmıştı. Temporomandibuler eklemin BT skoru, DAS28 ve modifiye Larsen skoru ile arasında bir korelasyon eğiliminin mevcut olduğunu gösterdi.

Sonuç: Çok kesitli bilgisayarlı tomografi ve MPR, RA hastalarında klinik belirtiler ve hastalık aktivitesi ile ilişkili TME tutulumunun hesaplanmasında tanısal açıdan güvenilir bir yöntemdir. Semptomatik TME olan RA hastaları için erken değerlendirme büyük önem taşır.

Anahtar sözcükler: Multiplanar rekonstrüksiyon; çok kesitli bilgisayarlı tomografi; romatoid artrit; temporomandibuler eklem.

Received: September 5, 2011 Accepted: January 9, 2012

Correspondence: Tamer Gheita, M.D. Department of Rheumatology, Faculty of Medicine, Cairo University, 12613 Cairo, Egypt.

Tel: 002025085372 e-mail: gheitamer@yahoo.com

(o2012 Turkish League Against Rheumatism. All rights reserved. 
The temporomandibular joint (TMJ) is commonly influenced in patients with rheumatoid arthritis $(\mathrm{RA})^{[1,2]}$ and is usually among the last joints to be affected. ${ }^{[1]}$ Arthritis is difficult to diagnose at an early stage as few symptoms and clinical findings are related to this joint. ${ }^{[3]}$ When RA manifests in an atypical manner, TMJ involvement poses a diagnostic dilemma. ${ }^{[1]}$ Due to its frequently silent course, temporomandibular arthritis tends to be not only a diagnostic challenge but also a therapeutic one. ${ }^{[4]}$

Involvement and dysfunction of the TMJ in RA patients has been described, but the incidence varies greatly from $2-86 \% .^{[5,6]}$ This could be attributed to differences in race, gender, age, and disease duration in the studied populations. Manifestations are diverse and include pain, restricted range of movement, crepitations, tenderness on palpation of the joint and the masticatory muscles, and locking. ${ }^{[7]}$ However, the extent of temporomandibular dysfunction (TMD) in RA and its clinical relevance have not been well characterized. The severity of TMD variably correlates with RA severity. ${ }^{[10]}$

The development of multislice computed tomography (CT), or MSCT, has been a major leap forward in CT technology ${ }^{[11]}$ It has brought about major advances in bone and joint imaging and is the modality of choice for assessing the TMJ and mild bony changes accompanied by RA since they can be clearly revealed due to the high resolution of MSCT. ${ }^{[7,12,13]}$ Multiplanar reconstruction (MPR) from MSCT shows the highest accuracy and allows for excellent imaging of discrete bony changes in TMJ arthritis. ${ }^{[14]}$

Typical findings in RA include subjective symptoms, restricted TMJ movement, and radiographic lesions along with condylar erosion, cysts, flattening, and sclerosis. ${ }^{[2]}$ Clinically, a high score in hand-joint space narrowing in RA serves as an early indicator of patients at risk for severe TMD. ${ }^{[10]}$ Given the paucity of clinical symptoms, magnetic resonance imaging (MRI) enhanced with gadolinium should be considered in the detection of TMJ arthritis. ${ }^{[15]}$ The use of ultrasonography (US) for the screening of TMJ arthritis is not advisable due to its low sensitivity in detecting structural damage. Although MRI appears to be a superior suggestion, its validity needs further revision. There is a need to find risk factors for TMJ involvement and to develop a feasible screening method for the early diagnosis of arthritis. ${ }^{[16]}$

There is no generally accepted TMJ grading system for juvenile idiopathic arthritis (JIA) severity, and only a few scoring systems have been suggested for adult RA. ${ }^{[17]}$ In children with RA, the TMJ is involved in up to $87 \%$ of cases, with half of them being asymptomatic. ${ }^{[18]}$ Long-term JIA manifestations in TMJs, as demonstrated by CT and MRI, were frequent, usually bilateral, and characterized by mandibular condyle and temporal bone deformities. ${ }^{[19]}$ Unilateral TMJ involvement occurs in $30-40 \%$ of patients with $\mathrm{RA}$, and higher rates of bilateral involvement occur as the numbers of joints affected increases. ${ }^{[16]}$ For the diagnosis of TMJ disorders, MRI should not be accepted as a gold standard. Some of the advanced osseous changes of the condyle, such as erosions, osteophytosis, and sclerosis have not often been detected. ${ }^{[20]}$ Moreover, the changes shown by MRI and its relation to the clinical symptoms were not obvious. ${ }^{[21]}$ Compared to CT, MRI has the disadvantage of limited spatial resolution and the magnetic susceptibility of bone. ${ }^{[20]}$ One of the widespread uses of MSCT is the attainment of MPR images for the diagnosis of bone changes of the TMJ. Definite criteria for such changes in RA have not yet been established. Accordingly, MPR was the imaging modality of choice in this study and was applied to clarify the incidence of bone changes of the TMJ in RA as an attempt to assess its diagnostic potential in these cases.

This work was undertaken to assess the osseous involvement of TMJ in RA patients by MSCT scanning with MPR and to find any relation to the clinical, laboratory, and radiological disease parameters.

\section{PATIENTS AND METHODS}

Twenty-four female patients (mean age 35.5 \pm 6.6 years; range 38.3 to 42 years) with definitive RA, as diagnosed by the 2010 American College of Rheumatology/European League Against Rheutatism (ACR/EULAR) RA classification criteria, ${ }^{[22]}$ were consecutively recruited from the rheumatology outpatient clinic and department of the Cairo University Hospitals. Their meandisease duration was 10.5 \pm 5.0 years (range 9.5-20 years). A complete medical history was obtained from each patient, and a thorough clinical examination of the joints with a detailed examination of the TMJ along with laboratory and plain X-rays of the TMJ, hands, cervical spine, and any other affected joints were performed for all the patients. All patients had disease duration of more than five years and were regularly receiving methotrexate (MTX) either with or without corticosteroids or hydroxychloroquine. The disease activity score in 28 joints (DAS28) 
was calculated, ${ }^{[23]}$ and the Health Assessment Questionnaire-II (HAQ-II) was used. ${ }^{[24]}$

To have standardized measurements of maximum mouth openings, patients with missing anterior teeth were excluded, and to maintain the maximum opening, a mouth probe was used. The maximum interincisor mouth opening (MIO) was measured using a vernier caliper. The 48 TMJs of the RA patients were assessed according to the TMJ clinical dysfunction score (CDS) as the presence of TMJ symptoms and signs were recorded. ${ }^{[25]}$ Radiological grading of the hands and feet of the studied RA patients was assessed, and percentage damage was calculated according to the modified Larsen score. ${ }^{[26]}$ Informed consents were obtained from the patients, and the local ethics committee approved the study.

\section{Multislice computed tomography scanning}

All the patients were referred to the Diagnostic Radiology Department, Faculty of Medicine, Cairo University for axial MSCT scanning in the opened and closed mouth positions. The examinations were performed using a quad slice Light Speed ${ }^{\circledR}$ CT scanner (General Electric, Milwaukee, USA). In an attempt to eliminate inter-observer errors, the reconstructed coronal and sagittal views were independently assessed by three radiologists (two maxillofacial radiologists and one general radiologist) at two different sessions without any knowledge of the clinical data. Each radiologist performed the assessment twice with a one-week interval between each assessment. Both the reconstructed coronal and corrected sagittal views were assessed for the shape of the mandibular condyle, presence of any bony abnormalities, and condylar position during maximal mouth opening by using the CT TMJ score. ${ }^{[25]}$ For optimum visualization of the anatomical structures under examination, a bone reconstruction algorithm was used. The obtained axial images were transformed into isotropic coronal and corrected sagittal images to obtain MPR for visualization of the articular surfaces.

\section{Statistical analysis}

The data were collected, tabulated and analyzed by Statistical Package for the Social Sciences (SPSS, Inc., Illinois, Chicago, USA) version 15.0 software. Data was summarized as mean \pm standard deviation [(SD) median (minimum-maximum)]. The MannWhitney U-test was used to compare two independent groups in terms of continuous variables. Spearman's correlation analysis was used for detection of the relationship between two variables. Logistic regression analysis was applied to detect the MSCT radiographic predictors for the occurrence of each of the clinical findings. The dependent clinical variables were as follows: difficulty in manipulation of TMJ, the occurrence of pain, locking, the occurrence of pain on palpation (tenderness), clicking, and abnormal quality of opening. The independent variables (predictors) were the following: the shape of mandibular condyle, flattening of articular eminence, erosion of articular eminence, erosion of mandibular condyle, erosion of articular fossa, mandibular subchondral cyst, osteophytosis, mandibular subchondral sclerosis, and position of mandibular condyle. The results were considered statistically significant at $\mathrm{p}<0.05$.

\section{RESULTS}

There were 17 symptomatic and seven asymptomatic patients for TMJ. Three of the seven with asymptomatic TMJ had a history of TMJ pain and tenderness at the disease onset but had been free of TMJ pain for more than a year before the study. Furthermore, 10 of those with TMJ involvement had history of TMJ complaints at disease onset. The TMJs were bilaterally involved in all patients; however, clinical features such as tenderness, clicking, and locking were unilateral in $8.33 \%, 4.17 \%$ and $4.17 \%$, respectively. The MSCT findings were bilaterally present but had varying degrees of severity.

The RA patients were receiving a mean steroid dose of $4.38 \pm 3.92 \mathrm{mg} /$ day [5 (0-15)] and a mean methotrexate dose of $17.71 \pm 2.07 \mathrm{mg} /$ day [17.5 (15-20)]. The clinical features of the RA patients included the following: morning stiffness: $98.75 \pm 24.19 \mathrm{~min}$ [105 (60$120)]$, tenderness score: $14.96 \pm 5.77$ [20 (5-20)], swollen joints count: $3.25 \pm 1.94$ [2 (1-8)], DAS28: $5.31 \pm 0.6$ [5.22 (4.08-6.12)], HAQ-II: $1.19 \pm 0.68$ [1 (0.3-2.4)], and TMJ CDS: $2.63 \pm 2.3[2(0-7)]$. Regarding the radiological features, the mean Larsen score in the RA patients was $25.83 \pm 20.17$ [25.5 (4-61)], the percentage of radiological damage was $12.92 \pm 10.09$ [12.75 (2-30.5)], and the CT TMJ score was $3 \pm 3.39$ [1 (0-8)]. The demographic, clinical, and radiological features of the RA patients, both with and without symptomatic TMJ involvement are shown in Table 1. The laboratory investigations performed for the RA patients were as follows: hemoglobin level: $10.83 \pm 1.04 \mathrm{~g} / \mathrm{dl}$ [10.55 (9.6-13.5)], white blood cell (WBC) count: $7.54 \pm 2.59 \times 10^{3} / \mathrm{mm}^{3}$ [7.53 (4.1-10.3)], platelet count: $408.58 \pm 94.15 \times 10^{3} / \mathrm{mm}^{3}$ [440 (211-506)], erythrocyte sedimention rate (ESR): $49.88 \pm 21.58$ first hour $/ \mathrm{mmHg}$ [40.5 (25-92)], creatinine: $0.67 \pm 0.09 \mathrm{mg} / \mathrm{dl}[0.69(0.5-0.8)]$, urea: $21.58 \pm 5.4 \mathrm{mg} / \mathrm{dl}$ 


\begin{tabular}{|c|c|c|c|c|c|c|c|}
\hline & \multicolumn{6}{|c|}{ TMJ in RA patients $(n=24)$} & \multirow[b]{3}{*}{ Sig. $p$} \\
\hline & \multicolumn{3}{|c|}{ Symptomatic $(\mathrm{n}=17)$} & \multicolumn{3}{|c|}{ Asymptomatic $(\mathrm{n}=7)$} & \\
\hline & Mean \pm SD & Median & (min.-max.) & Mean \pm SD & Median & (min.-max.) & \\
\hline \multicolumn{8}{|l|}{ Features } \\
\hline Age (years) & $37.47^{\star} \pm 5.44$ & 40 & $26-42$ & $30.57 \pm 7.11$ & 25 & $25-40$ & 0.047 \\
\hline Disease duration (years) & $12.29^{\star} \pm 4.77$ & 14 & $6-20$ & $6.29 \pm 2.56$ & 5 & $5-12$ & 0.001 \\
\hline Age at disease onset (years) & $25.18 \pm 5.16$ & 24 & $19-36$ & $24.29 \pm 5.56$ & 20 & $20-33$ & 0.72 \\
\hline Steroid dose (mg/day) & $4.71 \pm 4.13$ & 5 & $0-15$ & $3.57 \pm 3.49$ & 2.5 & $0-10$ & 0.51 \\
\hline Methotrexate dose (mg/day) & $17.21^{\star} \pm 2.14$ & 17.5 & $15-20$ & $18.93 \pm 1.34$ & 20 & $17.5-20$ & 0.03 \\
\hline \multicolumn{8}{|l|}{ Clinical features } \\
\hline Morning stiffness (minutes) & $105.88 \pm 18.73$ & 120 & $60-120$ & $81.43 \pm 28.54$ & 60 & $60-120$ & 0.07 \\
\hline RAI (tenderness score) & $15.71 \pm 5.41$ & 20 & $7-20$ & $13.14 \pm 6.64$ & 11 & $5-20$ & 0.39 \\
\hline Swollen joints (count) & $3.35 \pm 2.09$ & 2 & $2-8$ & $3 \pm 1.63$ & 4 & $1-5$ & 0.67 \\
\hline HAQ-II & $1.31 \pm 0.69$ & 1.1 & $0.3-2.4$ & $0.9 \pm 0.6$ & 0.8 & $0.3-1.8$ & 0.17 \\
\hline DAS28 & $5.5^{\star} \pm 0.5$ & 5.44 & $4.95-6.12$ & $4.86 \pm 0.6$ & 4.87 & $4.08-5.79$ & 0.03 \\
\hline CDS (48 joints) & $3.71^{*} \pm 1.83$ & 3 & $2-7$ & 0 & - & - & $<0.001$ \\
\hline \multicolumn{8}{|l|}{ Radiological features } \\
\hline Larsen score & $27.41 \pm 19.95$ & 27 & $4-61$ & $22 \pm 21.79$ & 9 & $4-61$ & 0.58 \\
\hline Radiological damage (\%) & $13.71 \pm 9.98$ & 13.5 & $2-30$ & $11 \pm 10.89$ & 4.5 & $2-30.5$ & 0.58 \\
\hline CT TMJ score (of the 48 joints) & $5.29^{*} \pm 3.96$ & 5 & $0-8$ & $0.86 \pm 1.06$ & 0 & $0-2$ & $<0.001$ \\
\hline
\end{tabular}

[22 (10-30)], uric acid: $4.21 \pm 0.66 \mathrm{mg} / \mathrm{dl}$ [4 (3.5-6.1)], aspartate aminotransferase (AST): $19.25 \pm 11.61 \mathrm{U} / \mathrm{L}:[20$ (5-39)], alanine aminotransferase (ALT): $19 \pm 9.45 \mathrm{U} / \mathrm{L}$ : [17 (7-42)], alkaline phosphatase: $123.38 \pm 39.66 \mathrm{IU} / \mathrm{L}$ : [120 (73-213)], and albumin: $4.13 \pm 0.23 \mathrm{~g} / \mathrm{dl}$ [4.1 (3.74.6)]. Only the ESR was significantly higher in patients with TMJ involvement $(\mathrm{p}=0.004)$. The rheumatoid factor (RF) was positive in 18 patients $(75 \%)$ while the anti-CCP was positive in $83.33 \%$, including all those with TMJ involvement. The antinuclear antibody (ANA) was positive in seven patients.

There was atlantoaxial subluxation in four patients (three with TMJ involvement), Sjögren's syndrome in six (25\%) (five with TMJ involvement), and rheumatoid nodules in nine patients (eight with TMJ involvement and one without). Hypothyroidism was present in two patients (one with TMJ involvement and one without). Hydroxychloroquine was received by 12 patients (seven with TMJ involvement and five without).

The TMJ clinical and corrected sagittal MSCT findings are shown in Table 2. Symptomatic TMJ involvement was present in 17 of the RA patients while the TMJ osseous involvement detected by MPR MSCT scan became more frequent $(83.33 \%)$ as it involved three additional asymptomatic cases. The radiographic findings of the TMJ are presented in Figure 1. The mean CT TMJ score of all the RA patients was $4 \pm 3.93$. There was no significant difference between the constructed coronal and corrected sagittal MSCT findings except for a higher frequency of detection of mandibular condylar shape alteration by the coronal plane $(\mathrm{p}=0.043)$.

The TMJ CDS significantly correlated with the DAS28 score $(\mathrm{r}=0.48, \mathrm{p}=0.049)$ and the CT TMJ score $(\mathrm{r}=0.77, \mathrm{p}<0.001)$ while there was a tendency for an association with the modified Larsen score $(r=0.44$, $\mathrm{p}=0.078$ ). The CT TMJ score showed a tendency to correlate with the DAS28 $(\mathrm{r}=0.47, \mathrm{p}=0.06)$ and the modified Larsen score $(\mathrm{r}=0.47, \mathrm{p}=0.056)$. Furthermore, the DAS28 significantly correlated with the HAQ-II $(\mathrm{r}=0.71, \mathrm{p}=0.002)$, and both significantly correlated with the modified Larsen score $(r=0.66, p=0.004$ and $\mathrm{r}=0.71, \mathrm{p}=0.001$, respectively).

Upon studying the independent variables for the presence of clinical manifestations, the erosions of the articular eminence and mandibular condyle were the only radiological predictors of pain on palpation (tenderness). (Odds ratio $=8.23, \mathrm{p}=0.009$ and odds ratio $=0.01, \mathrm{p}=0.011$, respectively). There were no other significant radiological predictors for other clinical dysfunction features (Table 3). 


\begin{tabular}{|c|c|c|}
\hline & \multicolumn{2}{|c|}{ TMJ findings in RA patients ( $\mathrm{n}=24,48$ joints) } \\
\hline & No. of joints & $\%$ \\
\hline \multicolumn{3}{|l|}{ Clinical dysfunction $(\mathrm{n}=17)$} \\
\hline Difficult manipulation & 34 & 70.83 \\
\hline Pain & 34 & 70.83 \\
\hline Locking & 8 & 16.67 \\
\hline Tenderness & 22 & 45.83 \\
\hline Clicking & 14 & 29.17 \\
\hline Altered opening (lateral or S-shaped) & 4 & 8.33 \\
\hline Maximum interincisor mouth opening $<30 \mathrm{~mm}$ & 10 patients & 41.67 \\
\hline \multicolumn{3}{|l|}{ Corrected sagittal multislice CT findings $(n=20)$} \\
\hline Altered shape of mandibular condyle & 18 & 37.5 \\
\hline Flattening of the articular eminence & 20 & 41.67 \\
\hline Erosions of the articular eminence & 12 & 25 \\
\hline Erosions of the mandibular condyle & 30 & 62.5 \\
\hline Erosions of the articular fossa & 18 & 37.5 \\
\hline Mandibular subcondral cysts & 10 & 20.83 \\
\hline Condylar head resorption & 0 & 0 \\
\hline Mandibular fracture & 0 & 0 \\
\hline Bony ankylosis & 0 & 0 \\
\hline Osteophytosis & 16 & 33.33 \\
\hline Mandibular subcondral sclerosis & 20 & 41.67 \\
\hline Altered condyle position (open mouth) & 26 & 54.17 \\
\hline Maximum interincisor mouth opening $<30 \mathrm{~mm}$ & 10 patients & 41.67 \\
\hline
\end{tabular}

\section{DISCUSSION}

In the present study, symptomatic TMJ involvement was present in $70.83 \%$ of the RA patients. The joints were bilaterally involved in all patients; however, in a small number of cases, someclinicalfeaturessuch astenderness, clicking, and locking were unilateral. The most frequent clinical TMJ dysfunction manifestations were difficult manipulation and pain, tenderness (45.83\%), clicking (29.17\%), and locking (16.67\%) followed by altered mouth opening (8.33\%). The TMJ osseous involvement became more frequent (83.33\%), and bilateral usage of the MPR MSCT scans in the RA patients increased with the three additional asymptomatic cases (12.5\%). The most frequent findings were mandibular condyle erosions (62.5\%), altered condyle position (54.17\%), mandibular subchondral sclerosis (41.67\%), articular eminence flattening (41.67\%), altered condyle shape and articular fossa erosion (37.5\%), osteophytes (33.33\%), articular eminence erosion (25\%), and mandibular subcondral cysts $(20.83 \%)$. The MIO was reduced $<30$ $\mathrm{mm}$ in $41.67 \%$ of the patients.

Similarly, clinical and CT examination of the TMJ in RA patients revealed physical signs in $61.2 \%$ and erosive or cystic lesions in $88.4 \% .{ }^{[27]}$ However, lower TMJ involvement (45\%) was detected by imaging (CT and MRI) techniques, and the most frequent radiological signs were osteophyte formation, erosion of the mandibular condyle, and decreased joint space. Even in asymptomatic RA patients, TMJ involvement may be detected. ${ }^{[5]}$ A lower frequency (55\%) of TMD was present in another study on RA cases that showed at least one sign or symptom. ${ }^{[28]}$ Signs of TMJ arthritis on MRI were present in $63 \%$ of JIA patients and $53 \%$ of the joints. Condylar deformity was present in $47 \%$ of patients and $45 \%$ of the joints. When comparing rheumatological, orthodontic, and US examinations with MRI, they misdiagnosed $42 \%$, 53\% and $67 \%$ of patients, respectively, as having no signs of inflammation. ${ }^{[16]}$ The TMJs were involved in $70 \%$ of the JIA patients, and all main joint components were abnormal in $84.85 \%$, mainly showing flat deformed condyles and wide flat fossae. Condylar concavity and secondary osteoarthritis were found in approximately half of the abnormal joints. ${ }^{[19]}$ On radiography, 78\% of JIA patients had condylar lesions. ${ }^{[28]}$ Condylar resorption was especially found in those with a polyarticular onset or course of disease, as they were 

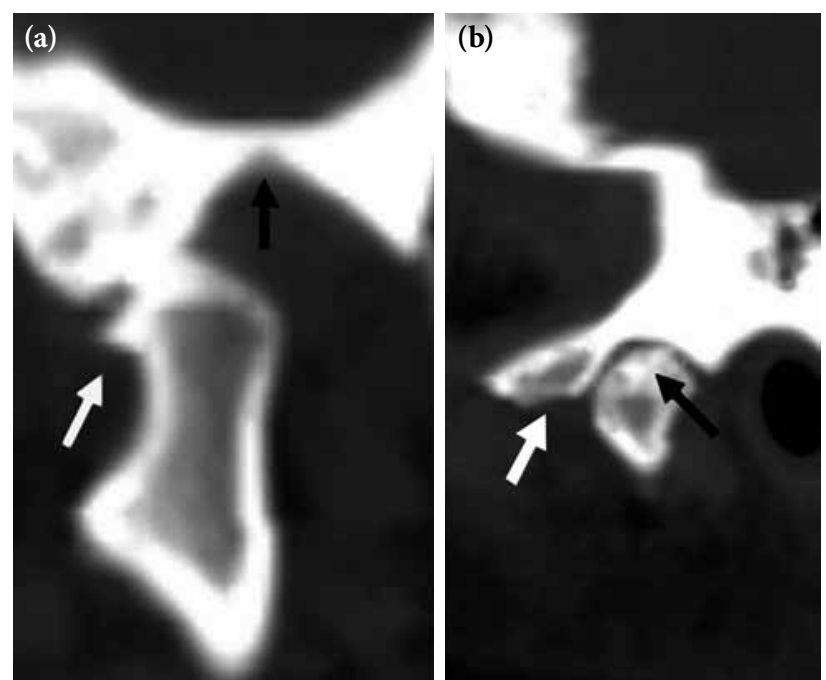

Figure 1. Corrected sagittal image of the temporomandibular joint. (a) Corrected sagittal image of the joint in opened mouth position showing erosion of the articular fossa (black arrow) and osteophytosis (white arrow) as well as the presence of the mandibular condyle in posterior relation to the eminence. (b) Closed mouth position showing flattening and erosion of the articular eminence (white arrow) and mandibular subchondral sclerosis (black arrow).

more frequently severe. ${ }^{[29]}$ The CT radiographic signs of TMJ involvement included erosion, flattening, sclerosis, subchondral pseudocysts, and osteophytes, with the most frequent being sclerosis (75\%), erosion
(50\%), and flattening (30\%). ${ }^{[30]}$ In another study, an abnormal condyle was observed in $32 \%$ of RA patients, flattened articular eminence in $27 \%$, flattened articular disks in $17 \%$, and restricted condylar motion in $9 \% \cdot{ }^{[31]}$ In RA, clicking was the most frequent sign of TMJ involvement (48.8\%). It was radiologically detected in $76.7 \%$ of patients, with synovial proliferation being the most frequent finding (51.1\%). ${ }^{[9]}$ A 40-46\% limited mouth opening in RA patients has been reported. ${ }^{[2]}$ All the clinical findings in the present study were in harmony with the findings of Lin et al. ${ }^{[10]}$ Similarly, it has been reported that nearly all RA patients had TMD symptoms and that almost all of them had positive findings in high resolution CT images. ${ }^{[32]}$

The TMJ CDS significantly correlated with the DAS28 and CT TMJ scores, but there was only a tendency for an association with the modified Larsen score. The CT TMJ score showed a tendency to correlate with the DAS28 and the modified Larsen score. Conversely, the CDS did not correlate with the CT TMJ score in RA, but it correlated with the RF titer and radiographic scores of the hands and cervical spine. The intensity of destructive lesions of TMJ on CT correlated significantly with the severity of the disease. ${ }^{[27]}$

In the present study, the age of the patients and disease duration increased significantly in those with symptomatic TMJ involvement. Likewise, the age,

Table 3. Temporomandibular joint dysfunction in rheumatoid arthritis patients

\begin{tabular}{|c|c|c|c|c|c|c|c|c|c|c|c|c|}
\hline \multirow{3}{*}{$\begin{array}{l}\text { Radiographic features } \\
\text { (predictors) }\end{array}$} & \multicolumn{12}{|c|}{ Clinical manifestations of TMJ dysfunction in RA patients $(n=24)$} \\
\hline & \multicolumn{2}{|c|}{$\begin{array}{c}\text { Difficult } \\
\text { manipulation }\end{array}$} & \multicolumn{2}{|c|}{ Pain } & \multicolumn{2}{|c|}{ Locking } & \multicolumn{2}{|c|}{ Tenderness } & \multicolumn{2}{|c|}{ Clicking } & \multicolumn{2}{|c|}{$\begin{array}{l}\text { Altered } \\
\text { opening }\end{array}$} \\
\hline & $\begin{array}{l}\text { Odds } \\
\text { ratio }\end{array}$ & $p$ & $\begin{array}{l}\text { Odds } \\
\text { ratio }\end{array}$ & $p$ & $\begin{array}{l}\text { Odds } \\
\text { ratio }\end{array}$ & $p$ & $\begin{array}{l}\text { Odds } \\
\text { ratio }\end{array}$ & $p$ & $\begin{array}{l}\text { Odds } \\
\text { ratio }\end{array}$ & $p$ & Odds & $p$ \\
\hline $\begin{array}{l}\text { Shape of the } \\
\text { mandibular condyle }\end{array}$ & 1.45 & 0.82 & 1.45 & 0.82 & 0.001 & 0.99 & 7.49 & 0.22 & 1.21 & 1 & 6.06 & 1 \\
\hline $\begin{array}{l}\text { Flattening of the } \\
\text { articular eminence }\end{array}$ & 0.001 & 0.81 & 0.001 & 0.81 & 4.92 & 1 & 0.36 & 0.5 & 0.001 & 0.98 & 0.25 & 1 \\
\hline $\begin{array}{l}\text { Erosion of the } \\
\text { articular eminence }\end{array}$ & 2.94 & 0.52 & 2.94 & 0.52 & 3.75 & 0.98 & $8.23^{*}$ & 0.009 & 0.001 & 0.98 & 2.01 & 1 \\
\hline $\begin{array}{l}\text { Erosion of the } \\
\text { mandibular condyle }\end{array}$ & 0.29 & 0.44 & 0.29 & 0.44 & 0.591 & 1 & $0.01^{\star}$ & 0.011 & 7.31 & 0.99 & 0.12 & 1 \\
\hline $\begin{array}{l}\text { Erosion of the } \\
\text { articular fossa }\end{array}$ & 6.68 & 0.15 & 6.68 & 0.15 & 6.483 & 1 & 0.17 & 0.13 & 6.23 & 0.98 & 0.001 & 0.99 \\
\hline $\begin{array}{l}\text { Mandibular } \\
\text { subchondral cyst }\end{array}$ & 8.13 & 0.09 & 8.13 & 0.09 & 1.384 & 1 & 8.45 & 0.08 & 1.39 & 0.95 & 0.22 & 1 \\
\hline Osteophytosis & 0.57 & 0.74 & 0.57 & 0.74 & 2.23 & 0.97 & 1.27 & 0.85 & 6.26 & 0.97 & 0.07 & 1 \\
\hline $\begin{array}{l}\text { Mandibular } \\
\text { subchondral sclerosis }\end{array}$ & 13.2 & 0.09 & 13.2 & 0.09 & 0.001 & 0.97 & 0.29 & 0.44 & 0.001 & 0.98 & 5.57 & 0.99 \\
\hline $\begin{array}{l}\text { Position of the } \\
\text { mandibular condyle }\end{array}$ & 1.17 & 0.9 & 1.17 & 0.9 & 0.001 & 0.99 & 0.21 & 0.21 & 3.87 & 0.99 & 3.34 & 0.99 \\
\hline
\end{tabular}


duration of disease, number of swollen joints, C-reactive protein (CRP), and RF levels as well as disease severity were found to be correlated with TMJ involvement. ${ }^{[5]}$ The progression of radiographic changes of the TMJ in RA patients is associated with raised CRP levels. ${ }^{[33]}$ In RA, clinical measurements of signs and symptoms of TMJ including pain during jaw movement, limitation of maximal mouth opening, and clicking along with joint and masticatory muscle tenderness on palpation correlated with the disease duration, RF positivity, the HAQ score, and number of tender and swollen joints. ${ }^{[34]}$ The presence of condylar damage was not related to clinical orthodontic findings or to JIA subtype, disease activity, severity, or duration. ${ }^{[28]}$

Even with other radiological modalities, the MRI findings as well as the ESR and RF were considered important indicators of TMJ involvement in RA, and a significant correlation was observed between the ESR and MRI findings. Furthermore, the clinical examination findings significantly correlated with the $\mathrm{RF}$ and with the findings of the MRI. ${ }^{[9]}$

Methotrexate was of a significantly higher dose in those patients who were asymptomatic for TMJ, and it was effective in minimizing TMJ destruction in juvenile RA patients. The patients receiving MTX showed less severe TMJ involvement than those not receiving it. ${ }^{[35]}$

The prolonged disease duration in the present study enhanced the chance to notice the effect of disease on the osseous component of TMJ. After five years of disease onset, $50-85 \%$ of RA patients show the full disease picture. ${ }^{[36]}$ Radiographic evidence of damage (erosion) occurs in almost all seropositive RA patients who are followed up for more than five years. ${ }^{[37]}$

Erosions of the articular eminence and mandibular condyle were the only radiological predictors of pain on pa lpation (tenderness) of the TMJ. (Odds ratio $=8.23$, $\mathrm{p}=0.009$ and $0.009,0.011$, respectively). There were no other significant radiological predictors for other features of clinical dysfunction. This was in accordance with the observed relationship between osseous erosions and TMJ tenderness. ${ }^{[2]}$ The best predictor for active TMJ arthritis on MRI was a reduced maximum mouth opening. ${ }^{[18]}$ For abnormal condyle and flattened articular eminence, independent predictors and risk factors for TMJ damage were a systemic type of JIA, young age at onset, and long disease duration. ${ }^{[31]}$

In the present study, Sjögren's syndrome was shown in $25 \%$ of the cases. In another study, a higher frequency of TMJ and salivary gland dysfunction in RA patients was demonstrated, and disease activity (DAS28) was associated with both hyposalivation and TMJ pain and dysfunction. ${ }^{[8]}$

In conclusion, to our knowledge, the present study is one of very few which estimates the diagnostic reliability of MPR MSCT of the TMJ with the clinical manifestations and disease activity in RA patients. Rheumatoid patients with symptomatic TMJ should be evaluated as early as possible by MSCT with MPR to consider its involvement in the treatment plans, including proactive dental management. The MSCT obviously could detect osseous TMJ involvement in a high percentage of asymptomatic RA patients. A study on a larger number of early RA patients is part of the scope of future studies.

\section{Declaration of conflicting interests}

The authors declared no conflicts of interest with respect to the authorship and/or publication of this article.

\section{Funding}

The authors received no financial support for the research and/or authorship of this article.

\section{REFERENCES}

1. Bathi RJ, Taneja N, Parveen S. Rheumatoid arthritis of TMJ-a diagnostic dilemma? Dent Update 2004;31:167-70, 172, 174.

2. Helenius LM, Hallikainen D, Helenius I, Meurman JH, Könönen M, Leirisalo-Repo $\mathrm{M}$, et al. Clinical and radiographic findings of the temporomandibular joint in patients with various rheumatic diseases. A case-control study. Oral Surg Oral Med Oral Pathol Oral Radiol Endod 2005;99:455-63.

3. Pedersen TK, Küseler A, Gelineck J, Herlin T. A prospective study of magnetic resonance and radiographic imaging in relation to symptoms and clinical findings of the temporomandibular joint in children with juvenile idiopathic arthritis. J Rheumatol 2008;35:1668-75.

4. Gönner-Ozkan V, Meyer P, Tzaribachev N. Interdisciplinary treatment of temporomandibular inflammation in children with juvenile idiopathic arthritis. Z Rheumatol 2010;69:130-4. [Abstract]

5. Celiker R, Gökçe-Kutsal Y, Eryilmaz M. Temporomandibular joint involvement in rheumatoid arthritis. Relationship with disease activity. Scand J Rheumatol 1995;24:22-5.

6. Gleissner C, Kaesser U, Dehne F, Bolten WW, Willershausen B. Temporomandibular joint function in patients with longstanding rheumatoid arthritis - I. Role of periodontal status and prosthetic care - a clinical study. Eur J Med Res 2003;8:98-108. 
7. Broussard JS Jr. Derangement, osteoarthritis, and rheumatoid arthritis of the temporomandibular joint: implications, diagnosis, and management. Dent Clin North Am 2005;49:327-42.

8. Moen K, Bertelsen LT, Hellem S, Jonsson R, Brun JG. Salivary gland and temporomandibular joint involvement in rheumatoid arthritis: relation to disease activity. Oral Dis 2005;11:27-34.

9. Ozcan I, Ozcan KM, Keskin D, Bahar S, Boyacigil S, Dere H. Temporomandibular joint involvement in rheumatoid arthritis: correlation of clinical, laboratory and magnetic resonance imaging findings. B-ENT 2008;4:19-24.

10. Lin YC, Hsu ML, Yang JS, Liang TH, Chou SL, Lin HY. Temporomandibular joint disorders in patients with rheumatoid arthritis. J Chin Med Assoc 2007;70:527-34.

11. Endo M, Mori S, Tsunoo T, Miyazaki H. Magnitude and effects of x-ray scatter in a 256-slice CT scanner. Med Phys 2006;33:3359-68.

12. Buckwalter KA, Rydberg J, Kopecky KK, Crow K, Yang EL. Musculoskeletal imaging with multislice CT. AJR Am J Roentgenol 2001;176:979-86.

13. Zhen J, Liu C, Wang S, Liu S, He J, Wang J, et al. The thin sectional anatomy of the temporal bone correlated with multislice spiral CT. Surg Radiol Anat 2007;29:409-18.

14. Cara AC, Gaia BF, Perrella A, Oliveira JX, Lopes PM, Cavalcanti MG. Validity of single- and multislice CT for assessment of mandibular condyle lesions. Dentomaxillofac Radiol 2007;36:24-7.

15. Arabshahi B, Cron RQ. Temporomandibular joint arthritis in juvenile idiopathic arthritis: the forgotten joint. Curr Opin Rheumatol 2006;18:490-5.

16. Müller L, Kellenberger CJ, Cannizzaro E, Ettlin D, Schraner T, Bolt IB, et al. Early diagnosis of temporomandibular joint involvement in juvenile idiopathic arthritis: a pilot study comparing clinical examination and ultrasound to magnetic resonance imaging. Rheumatology (Oxford) 2009;48:680-5.

17. Arvidsson LZ, Flatø B, Larheim TA. Radiographic TMJ abnormalities in patients with juvenile idiopathic arthritis followed for 27 years. Oral Surg Oral Med Oral Pathol Oral Radiol Endod 2009;108:114-23.

18. Tzaribachev N, Weber D, Horger M. Juvenile idiopathic arthritis: the silent killer of pediatric temporomandibular joints. Z Rheumatol 2010;69:124-9. [Abstract]

19. Arvidsson LZ, Smith HJ, Flatø B, Larheim TA. Temporomandibular joint findings in adults with longstanding juvenile idiopathic arthritis: CT and MR imaging assessment. Radiology 2010;256:191-200.

20. Koyama J, Nishiyama H, Hayashi T. Follow-up study of condylar bony changes using helical computed tomography in patients with temporomandibular disorder. Dentomaxillofac Radiol 2007;36:472-7.

21. Tvrdy P. Methods of imaging in the diagnosis of temporomandibular joint disorders. Biomed Pap Med Fac Univ Palacky Olomouc Czech Repub 2007;151:133-6.
22 Aletaha D, Neogi T, Silman AJ, Funovits J, Felson DT, Bingham CO 3rd, et al. 2010 Rheumatoid arthritis classification criteria: an American College of Rheumatology/European League Against Rheumatism collaborative initiative. Arthritis Rheum 2010;62:2569-81.

23. Prevoo ML, van't Hof MA, Kuper HH, van Leeuwen MA, van de Putte LB, van Riel PL. Modified disease activity scores that include twenty-eight-joint counts. Development and validation in a prospective longitudinal study of patients with rheumatoid arthritis. Arthritis Rheum 1995;38:44-8.

24. Wolfe F, Michaud K, Pincus T. Development and validation of the health assessment questionnaire II: a revised version of the health assessment questionnaire. Arthritis Rheum 2004;50:3296-305.

25. Goupille P, Fouquet B, Cotty P, Goga D, Mateu J, Valat JP. The temporomandibular joint in rheumatoid arthritis. Correlations between clinical and computed tomography features. J Rheumatol 1990;17:1285-91.

26. Larsen A. How to apply Larsen score in evaluating radiographs of rheumatoid arthritis in long-term studies. J Rheumatol 1995;22:1974-5.

27. Goupille P, Fouquet B, Goga D, Cotty P, Valat JP. The temporomandibular joint in rheumatoid arthritis: correlations between clinical and tomographic features. J Dent 1993;21:141-6.

28. Billiau AD, Hu Y, Verdonck A, Carels C, Wouters C. Temporomandibular joint arthritis in juvenile idiopathic arthritis: prevalence, clinical and radiological signs, and relation to dentofacial morphology. J Rheumatol 2007;34:1925-33.

29. Pedersen TK, Jensen JJ, Melsen B, Herlin T. Resorption of the temporomandibular condylar bone according to subtypes of juvenile chronic arthritis. J Rheumatol 2001;28:2109-15.

30. Voog U, Alstergren P, Eliasson S, Leibur E, Kallikorm $\mathrm{R}$, Kopp S. Inflammatory mediators and radiographic changes in temporomandibular joints of patients with rheumatoid arthritis. Acta Odontol Scand 2003;61:57-64.

31. Argyropoulou MI, Margariti PN, Karali A, Astrakas L, Alfandaki S, Kosta P, et al. Temporomandibular joint involvement in juvenile idiopathic arthritis: clinical predictors of magnetic resonance imaging signs. Eur Radiol 2009;19:693-700.

32. Ardic F, Gokharman D, Atsu S, Guner S, Yilmaz M, Yorgancioglu R. The comprehensive evaluation of temporomandibular disorders seen in rheumatoid arthritis. Aust Dent J 2006;51:23-8.

33. Nordahl S, Alstergren P, Eliasson S, Kopp S. Radiographic signs of bone destruction in the arthritic temporomandibular joint with special reference to markers of disease activity. A longitudinal study. Rheumatology (Oxford) 2001;40:691-4.

34. Bessa-Nogueira RV, Vasconcelos BC, Duarte AP, Góes PS, Bezerra TP. Targeted assessment of the temporomandibular joint in patients with rheumatoid arthritis. J Oral Maxillofac Surg 2008;66:1804-11. 
35. Ince DO, Ince A, Moore TL. The effect of methotrexate on the temporomandibular joint in polyarticular juvenile rheumatoid arthritis patients. J Clin Rheumatol 1999;5:320-5.

36. Tehlirian CV, Bathon JM. Rheumatoid arthritis: clinical and laboratory manifestations. In: Klippel JH, Stone JH, Crofford LJ, White PH, editors. Primer on the Rheumatic diseases. Chapter 5, 13th ed. New York: Saunders; 2008. p. 114-21.

37. O’Dell JR. Rheumatoid arthritis: Clinical aspects. In: Koopman WJ, Boulware DW, Heudebert G, Heudebert GR, editors. Clinical primer of rheumatology. Chapter 10, Philadelphia: Lippincott Williams \& Wilkins; 2003. p. 97-115. 